\section{ECONOMICS}

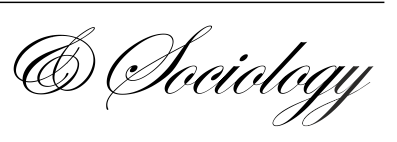

Hajduga, P., Pilewicz, T., Mempel-Śnieżyk, A. (2018). Cooperation between Local Authorities and Economic Entities in Polish Economic Zones - Evidence from Lower Silesia in Poland. Economics and Sociology, 11(2), 80-96. doi:10.14254/2071789X.2018/11-2/6

\title{
COOPERATION BETWEEN LOCAL AUTHORITIES AND ECONOMIC ENTITIES IN POLISH ECONOMIC ZONES - EVIDENCE FROM LOWER SILESIA IN POLAND
}

Piotr Hajduga,

Wroclaw University of Economics,

Wroclaw, Poland,

E-mail:piotr.hajduga@ue.wroc.pl

Tomasz Pilewicz,

Warsaw School of Economics,

Warsaw, Poland,

mail:tomas:pilewicz@sgh.waw.pl

\section{Anna Mempel-Śnieżyk, \\ Wroclaw University of Economics, Wroclaw, Poland, \\ E-mail:anna.sniesyk@ue.wroc.pl}

Received: January, 2018

1st Revision: March, 2018

Accepted: May, 2018

DOI: $10.14254 / 2071-$

789X.2018/11-2/6

\begin{abstract}
The article presents the phenomenon of special economic zones (SEZs) in Poland through characteristics of its legal, organizational and economic aspects. The detailed study of benefits and expectations from local authorities and managing authority of SEZs in Lower Silesia has been presented. The aim of this paper is to explain the phenomenon and the importance of cooperation between the enterprises located in special economic zones (SEZs) and also, between enterprises and local authorities. The authors hypothesize that participation in SEZs activities results in establishing cooperation among other entities within and beyond SEZs. For this paper, we designed and conducted a survey among economic entities seated in SEZs of Lower Silesia region.

A simple random sampling approach was used with a representative number of economic entities' subpopulations proportionally reflecting the size of enterprises (small, medium, large) in the studied population. The interview questionnaire comprises a set of 24 questions referring to various aspects in the functioning of enterprises in SEZs.

The conducted research have found that although research entities indicated legal obstacles, confusing regulations, shortage of personnel, or limited space for enterprise development in SEZs in Lower Silesia they qualified relationships with local authorities as very favourable and rather favourable. Despite the identified unfavourable conditions for conducting business the researched entities invested in new technologies, services and further expansion during their activity in SEZs. The researched entities also recognized the crucial role of the authority formally managing SEZs and their satisfaction resulting from relationships with local authorities.
\end{abstract}

JEL Classification: L14, L26, O18, R11
Keywords: special economic zone; networks of cooperation; local authorities, Poland 


\section{Introduction}

Nowadays, regional and spatial policy focuses more and more on supporting the development of network connections among business entities, local authorities and business environment. Reflections concerning the supportf for developing this cooperation, among other things, result from the benefits which it can reap from the development of particular regions or development on a local scale. It is also significant that cooperation among business entities is becoming ever more important and may be perceived as an instrument used for solving economic problems. Considering the importance and the topicality of the above issue, an attempt has been made to indicate the benefits from cooperation among particular entities and local authorities.

The authors are aware of the multitude of functioning economic forms and systems of network types and their variety; however, with regard to the conducted research, the article raises the issue of cooperation between the aforementioned entities in the light of special economic zones (SEZs). The paper concentrates on internal relations and their effects on enterprises active within SEZs. The definition and rules of functioning SEZs are outlined in the next part of the paper but it is worth mentioning that SEZ is an economically privileged and an administratively separate area. SEZs are perceived as contributing to economic development by offering investment incentives. They cluster foreign investors and create business climate, which in consequence, leads to spreading of know-how upgrading to domestic firms, which can then upgrade and can pull the rest of the country on a path of faster economic development (Johansson and Nilsson, 1997; Romer, 1993; Basile and Germidis, 1984; Litwack, 1998; Schrank, 2001 after Moberg, 2015, p. 167). Moreover, the issue of SEZs is developed in parallel by the following political economy approaches (Buchanan and Tullock, 1962; Khan, 2004 after Aggarwal, 2010, pp. 13-14) the heterodox approach (Chang, 2002; Milberg, 2007 after Aggarwal, 2010, pp. 14-15), the global value chain approach and agglomeration economies approach (Aggarwal, 2010, pp. 13-16). The paper relates to the agglomeration economies approach and economic development theories deriving from this approach (Perroux, 1950; Dahmén, 1950; Bagnasco, 1977; Becattini, 1977; Pyke and Sengenberger, 1992; Porter, 1990) and complements this theory in particular in the context of the importance of relations between local business and local authorities.

Although a significant amount of data has been gathered during our research the authors have purposefully decided to narrow down the presented results to items contributing to the goal of this paper.

The aim of this paper is to present the phenomenon and the importance of cooperation between enterprises located in SEZs and also between enterprises and local authorities in the aforementioned context. The article presents the phenomenon of SEZs in Poland through characteristics of their legal, organizational and economic aspects. The detailed study of benefits and expectations from local authorities and managing authorities of SEZs in Lower Silesia have been presented. The conducted empirical research has verified that the satisfaction of economic entities in SEZs deriving from relationships with local authorities and SEZs managing authorities might be crucial in justifying overall business benefits perception resulting from locating and conducting business in SEZs. Therefore, we regard further research on the nature, intensity and quality of such relationships as justified. Although a significant amount of data had been gathered during our research, the authors purposefully decided to narrow down the presented results to the items directly contributing to this paper's goal achievement. 


\section{Literature review}

\subsection{Activities and institutional framework for supporting and creating economic networks}

The concentration of enterprises on a particular territory, the specialisation and flexibility of production, network relations, and cooperation between entities have become an subject of many scientific disciplines and as a consequence, there are multiple definitions, and concepts. The relevant literature provides multiple divisions of network correlations which function in contemporary economy. In this context, it is worth pointing out the precursor of territorially concentrated enterprises. The original concept of the territorially concentrated enterprises was established by A. Marshall, who used the term "industrial district", while M. Porter in 1990 merely popularised the theoretical achievements of A. Marshall. Nevertheless, the relevant literature many times indicates M. Porter as the precursor of the term "cluster" in the economic aspect and reveals that his works exerted the greatest influence on the shape of the cluster concept. The classical Marshall's concept (Marshall, 1920) of the industrial district is indicated as the concept used in the new directions of research on the phenomena of changes in space, as well as one giving rise to research on specific forms of production. This concept explains the benefits of creating clusters as the first in the history of economic thought. Different typologies of clusters are to be found in the relevant literature: one by J. Meyer-Stamer (1999), others by the British Department of Trade and Industry (DTI) or by OECD.

Further research concerning industrial districts was affected by Italian economists and sociologists, who were trying to explain the phenomenon of the so-called Italian District ${ }^{1}$. The pioneers in the research on new industrial districts were G. Becattini (1992), A. Bagnasco (1977). They returned in their works to the notion of industrial district, while A. Bagnasco introduced a new type of industrial district called "Third Italy", this area comprised Venice, Trento - Upper Adige, Friuli - Julian March, Emilia - Romagna, Tuscany, March, Umbria, Latium (Pietrzyk, 2001, p. 44). K. Semlinger referring to industrial districts in Italy, explores the issue of the interplay between cooperation and competition in the network. He argues that mere co-location of entrepreneurial entities has to be supplemented by intentional cooperation. Moreover, he argues that regional collaboration should take place in cooperative networks of trusted partners (Semlinger, 2015, p. 547).

The concepts of progress, connected with the support of arising forms of cooperation, have been popular in Europe for many years and they belong to a trend of a new paradigm of local development. Those concepts refering to network structures emphasize agglomeration of product-based enterprises, service enterprises and institutions helping in their actions located in a particular area. The above-mentioned concepts emphasize interaction among particular entities which, as a result, enhances innovation capacity, increases the level of competitiveness and helps achieve a beneficial coefficient of social-economic development (e.g. Perroux, 1950; Dahmén, 1950; Bagnasco, 1977; Becattini, 1977; Pyke and Sengenberger, 1992; Porter, 1990). Particularly interesting is the theory of growth poles developed by the French regional economist F. Perroux (Perroux, 1950), which outlines that the process of growth in economic space appears in economic centres, which first attract development resources, and then repulse effects of their activities to broader economic space. The theory of F. Perroux, further developed by A. Hirschman has been used to develop

\footnotetext{
${ }^{1}$ This area comprised Venice, Trento - Upper Adige, Friuli - Julian March, Emilia - Romagna, Tuscany, March, Umbria, Latium.
} 
algorithms for public administration to attract and retain the investments with high spillovers potential for regional development processes (Komarovskiy, Bondaruk, 2013, pp. 31-42).

What is important in this aspect is the creation of a system of connections and mutual relations both among enterprises of a defined area and local authorities and institutions in the area of research (institutions of higher education, research centres). It can be stressed that for the proper formation of network structures, willingness and ability to cooperate among the mentioned entities is indispensable. Recent research on economics relations indicates the phenomenon of relationship capital, which derives from number, intensity and quality of relationships formed and which can be exchanged for other types of capital, including economic ones (García-Merino et al., 2014, pp. 2-7).

The spatial concentration of enterprises themselves is not enough as their development depends on economic actors' ability to organise friendly relations and skilful management of the system: cooperation and competition. It can be stated that the group of factors that determine the development of these specific spatial structures involves innovations, imitations, competition, making new professional contacts, cooperative relationships, tradition, a specialised staff, employees' skills or tacit knowledge. SEZs are created to support socio-economic development at the macroeconomic, regional and local levels.. They constitute zones of special privilege, apart from a possibility of cooperation, the concentration of enterprises in a designated area, and they offer given competitive strengths towards the areas outside the zones. It has been proved that economic entities active in SEZ create multiplier effects impacting the supply of tradeable goods and services for the local and regional population, and also multiplier effects impacting the income of the local and regional population. Both supply and income related with multiplier effects contribute to the process of economic development through higher intensity of trade and services (incl. the newly created ones) enabled by higher income of population within the area of SEZ impact (Domanski, Gwosdz, 2005, pp. 1-8). According to K. J. Hazakis, it worth mentioning that equally important are interactions inside (SEZ) which determine success or failure of zones (Haizakis, 2014, pp. 85-86).

Legally, SEZ constitutes an administratively separate part of the country's territory, within which a specific system of legal standards is applied. "A zone" means that this area is a compartment in the country's territory. The zone is described as "special" because it is connected with a particular, "special" way of governing by the law (see Ciżkowicz et al., 2017, pp. 571-572). The term "economic" means that the applied solutions refer to economic issues. Legal standards - introduced by an act establishing the zone - should secure, that is, enable or facilitate, performing particular economic tasks and goals. They are used as political tools. They are committed to creating business and investor-friendly environment and to attract entrepreneurs. The relevant studies focusing on the general theory of free economic zones, results of the functioning of SEZs in the economy, concerning their spatial aspects are presented e.g. by Grubel (1982), UNCTC (1991), McCalla (1990).

In the literature, there are various ways of naming this phenomenon concentrating on different determinants of development. The divisions of zones naming depend on the type of investment incentives and the legislation of the country they are located in. The zones also vary in function and territorial extent. The rules of operation of the zones have been changed many times. The first economically privileged zones appeared in 16th century in seaports and offered tax and duties exemptions. At the beginning of their existence, production in zones was prohibited and their dominant activities were free to trade. With time, products and services were introduced to zones (Kryńska, 2000, pp. 18-20). The ways and rules of operating privileged zones in the world have changed over time, the zones were called e.g. customs-free zone, export processing zone, special economic zone, free production zone, 
foreign trade zone or, one of the most popular, free economic zones (FEZ) (see UNCTC, 1991). For instance, in 1986 there were 176 export processing zones across 47 countries and in 2003 the number increased to over 3000 across 116 countries. Although the names are different, the general concept of these zones is similar. It is worth mentioning that the existing zones were replaced by a new form e.g. in India the export processing zones were replaced by new forms: SEZs with their benefits and incentives that were not available in the zones functioning earlier (Aggarwal, 2006, p. 4533).

The appearance of SEZs in Poland in 1995, as a new instrument of a regional policy of the state, was connected with the need for an active stimulation of the development of particular regions through focusing the stream of investment on their area.

From this point of view, economically privileged zones must be treated as an expression of interventionism, and its expected result is supposed to remove disparities in the development of particular regions through an active influence on economic and social conditions. The impact of the SEZs on the economy can be found in the literature (Kryńska, 2000; Okrańska, 2000; Fierla, 2000; Brdulak, 2003 after Godlewska-Majkowska et al., 2016, p. 193). The role of central authorities in creating an expected socio-economic environment of the region results from the adopted model of cooperation with regional and local authorities and permissible scope of intervention in a free market system (Kubin, 2010, pp. 8-10). In Poland the creation of an economically privileged zone is a sign of the so-called indirect intervention of the state into the economic zone, that is such intervention which consists of tax exemption system and tax preferences for those entities that operate their business within the zone. SEZ is an institution of administrative law, which has all the features characteristic of a special area. Economically, an investment privileged zone is one of the instruments of regional policy of the state.

There are several benefits that entrepreneur can count on within their area, namely: tax exemptions, infrastructural preparation of land for investment or objects for lease, legal aid, facilitating contacts with local authorities etc. It is worth mentioning that the functioning of SEZs is a form of state aid for these enterprises which function within their area in compliance with the granted authorization (see: Bell, 2016, p. 964). Therefore, it influences the efficiency of the entities in the zones in relation to economic entities not being supported, which mostly translates into lower tax costs and may constitute a form of building an advantage. As a result of a lower tax burden, for example, the price of products and services offered by enterprises operating in the zones may be lower (Kubin, 2010, p. 11). According to previous regulations in Poland, the number of SEZs does not increase and there are 14 SEZs, but the number of sub-zones (located within areas of SEZs) has increased. At the end of 2015, SEZs covered 19837 ha of space, located in 173 cities and 248 municipalities. Analyzing data from previous years indicates an upward trend. The total value of investment in SEZs amounted to PLN 111.7 billion at the end of 2015.

\subsection{Conditionality of creating and functioning of SEZs in Poland}

Functioning of SEZs is aimed at increasing competitiveness of producers and service providers, and the accumulation of many entities on a relatively small area, which allows for achieving positive effects of agglomeration (World Bank, 2008, p. 12 ). SEZs are define through concentration and development of economic activity. They are conducive to increasing GDP of national economies, and they also contribute to structural transformations within the economy: they promote the non-traditional producing sectors, encourage the development of a national entrepreneurship and openness of the economy (Baissac, 2011, p. 26). The following benefits are indicated as arising from SEZs functioning: foreign 
exchange income, FDI inflow, increase of budget revenue, export increase, upgrading skills, technology transfer, imitation effect, export diversification and efficiency increase of national enterprises.

Their interaction is particularly visible at a local level, where they contribute to employment increase, the inflow of capital expenditure and technology transfer, and also to lowering social assistance expenditure. SEZs have become an essential instrument of implementing a policy of attracting foreign capital and promoting growth based on export development (Farole, 2011, p. 17).

One can find similarities and differences between Polish SEZs. They are all supervised by the same subject, they have the same legal forms of company management (a joint-stock company, limited liability company), have the same provisions regulating the functioning of the SEZs, economic and social objectives, rules and forms of state aid. Among the differences there are formation date, area of the plot of SEZs, state aid intensity depends on Regional Aid Map, location of investment areas, specificity of firms operating in SEZs, degree of development, social infrastructure of the region, industrial traditions of the region, technical infrastructure in the SEZs and their immediate surroundings. The rules of their operations have evolved and entrepreneurs have received an exemption from income tax in accordance with the regional map until the end of zones' existence, permission have been granted for manufacturing operations and additionally selected service activities, SEZs can be established on private land under certain criteria.

Currently there are 14 Polish Special Economic Zones. The first SEZ in Poland was established as Euro-Park Mielec SEZ in 1995, one year later in 1996 the next two SEZs appeared: Katowicka SEZ and Suwalska SEZ. The next ten SEZs were created in 1997 (Kamienna Góra, Kostrzyńsko-Słubicka, Kraków, Słupsk, Starachowice, Tarnobrzeg „EUROPARK WISŁOSAN”, Wałbrzych SSE „INVEST-PARK, Warmińsko-Mazurska, Łódź and Legnica). The last SEZ was established in 2001 and it was Pomorska SEZ. Three of the presented SEZs are located in Lower Silesia region ( Kamienna Góra SEZ, Legnica SEZ and Wałbrzych SEZ).

As has been said befor, business activities within the area of SEZs are administratively and legally regulated (Zdyb, 1997, p. 273). The Act of 20 October 1994 on SEZs defines an SEZ as "an uninhabited part of the territory of the Republic of Poland separated in accordance with the provisions of this Act within which economic activity may be conducted under the rules determined herein" (Act on SEZs, 1994). This means that entities located within the area of the zones that meet the conditions in relation to the size of investment outlay or newly created workplaces, can take advantage of public aid in the form of exemption from income tax (CIT - from legal bodies, such as enterprises or PIT - from physical bodies, such as individuals, depending on the legal form used to run the business) and property tax (it is determined by municipality authorities).

At the time of establishing SEZs in Poland it was assumed that they will also serve to achieve the objective of an accelerated economic development of a selected territory of the country, particularly by means of (Act on SEZs, 1994):

- developing certain areas of economic activity,

- developing new technology and process solutions and their implementation in

the national economy,

- developing export,

- increasing competitiveness of goods produced and services rendered,

- developing the existing industrial assets and economic infrastructure,

- creating new workplaces,

- utilising unused natural resources subject to environmental regulations. 
There are 14 Polish Special Economic Zones. The first SEZ in Poland was established as Euro-Park Mielec SEZ in 1995, one year later in 1996 the next two SEZs appeared: Katowicka SEZ and Suwalska SEZ. The next ten SEZs were created in 1997 (Kamienna Góra, Kostrzyńsko-Słubicka, Kraków, Słupsk, Starachowice, Tarnobrzeg „EURO-PARK WISŁOSAN”, Wałbrzych SSE „INVEST-PARK, Warmińsko-Mazurska, Łódź and Legnica). The last SEZ was established in 2001 and it was Pomorska SEZ. Three of the presented SEZs are located in Lower Silesia region (Kamienna Góra SEZ, Legnica SEZ and Wałbrzych SEZ).

One can find similarities and differences between Polish SEZs. They are all supervised by the same subject, they have the same legal forms of company management (a joint-stock company, limited liability company), have the same provisions regulating the functioning of the SEZs, economic and social objectives, rules and forms of state aid. Among the differences there are: formation date, area of the plot of SEZs, state aid intensity depends on Regional Aid Map, location of investment areas, specificity of firms operating in SEZs, degree of development, social infrastructure of the region, industrial traditions of the region, technical infrastructure in the SEZs and their immediate surroundings. The rules of their operations have evolved and entrepreneurs have received an exemption from income tax in accordance with the regional map until the end of zones' existence, permission have been granted for manufacturing operations and additionally selected service activities (previously onlu production), SEZs can be established aslo on private land under certain criteria.

Currently, as the Ministry of Development and Investment has proclaimed, new SEZs ${ }^{6}$ legislation is being planned. It is intended to modify the criteria for granting tax exemptions to enterprises and let them obtain state aid anywhere in the country, outside SEZs. It is worth mentioning that the current SEZ Act will be applicable until the end of 2026.

\section{Methodological approach}

We have conducted research in SEZs of Lower Silesia region in order to determine the scale of cooperation among entities that share a common location and their impact on a surrounding social-economic space. The research allowed also to identify type and perception of relations among the entities that function within SEZ of Lower Silesia region and local authorities. The study, analyses and interpretation acquired data was conducted in the period from 2013 to 2015.

We have designed and conducted a survey among economic entities seated in SEZs of Lower Silesia region. This region is perceived by foreign investors as interesting not only because of the infrastructure, specific geographic location but also because of people which are noticed as "able to be entrepreneurial and to become cosmopolitan, probably more flexible than in other Polish regions and in investors' opinions it is easier in Lower Silesia to cooperate and introduce innovations, because people are more flexible (Büttner, Heidenreich, 2005, p. 13).

A simple random sampling approach was used with representative amounts for a factor of enterprise size, which reflects the structure present in the analysed sample. The sampling frame was a database of enterprises registered as operating within three SEZs: Kamienna Góra, Legnica and Wałbrzych. The sampling frame included 180 records. Statistical representativeness of the results was guaranteed by conducting 50 standardised interviews, assuming that the size of the enterprise is reflected by the following amounts: 14 large enterprises (28\% surveyed enterprises), 16 medium-sized enterprises (32\%), 20 small and micro enterprises (40\%). The criterion of the enterprise size was presupposed in view of the Polish economic legislation, which stipulates enterprise division into large, medium-sized and small ones. Micro enterprises were included in the group of small enterprises. The 
adopted methodology met the condition of representativeness of results for each particular amount, and the whole collectivity of enterprises with seat in SEZs in Lower Silesia. In this survey the forms of a phone and direct interviews were adopted. In relation to business entities, respondents of the questionnaire were the people who hold managerial positions or are responsible within the enterprise, for contacts with authorities of the economic zones in question who have most extensive knowledge of strategic aspects of business operations mentioned in the survey. Interview questionnaire contained 24 questions referring to many aspects connected with the functioning of enterprises in SEZs. From the point of view of the issue undertaken in this article the most important are those referring to the causes of operating a business in the zone, evaluation of cooperation with local authorities and zone managing enterprise, costs and also benefits of operating a business in the particular zone.

Empirical research has been conducted in order to identify entrepreneurs' opinions and evaluations of key aspects of conducting business in the territory where the regulations for SEZs are in force. The information received during research was used to analyse the results. To achieve this, basic methods of descriptive statistics were used, namely the analysis of structure and variability of phenomena. Apart from this, also the method of comparative analysis and classic methods of inference - induction, deduction and reduction - were applied. Sampling approach, research methods, techniques and instruments have been presented in the picture below.

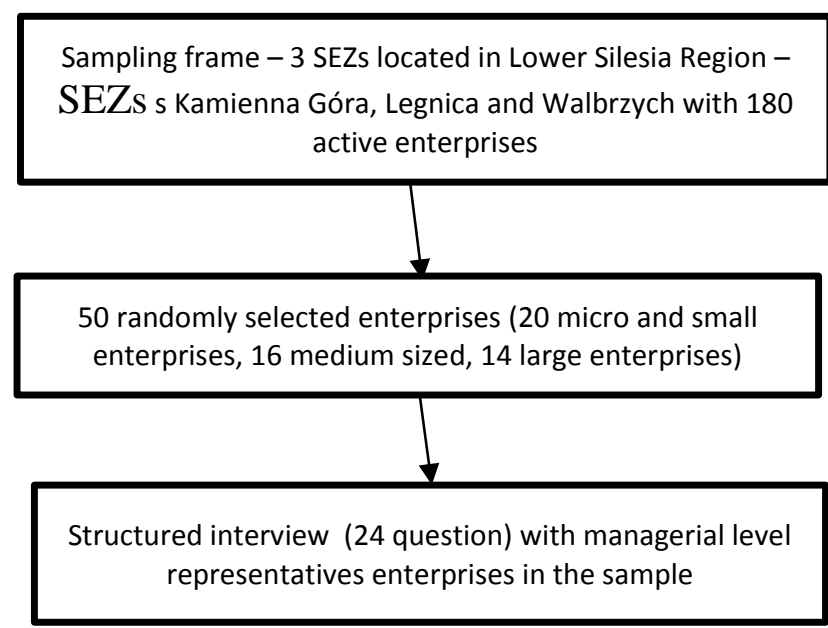

Figure1. Sampling approach, research methods, techniques and instruments Source: own elaboration.

\section{Conducting research and results}

The research conducted on 50 enterprises let us answer the question related to cooperation inside the SEZs and between enterprises and local authorities. In the research, we checked if the investigated enterprises previously operated in the market outside of the SEZ (cf. Table 1). As results from the research, we find out that $66 \%$ of them operated outside of SEZ before they started the activity. 
Table 1. Structure of the investigated enterprises according to their previous operation in the market outside of SEZ

\begin{tabular}{lrrrrrrrr}
\hline & in total & \multicolumn{1}{l}{ yes } & \multicolumn{1}{c}{ no } & A & B & C & \multicolumn{1}{c}{ D } \\
\hline large & $\mathbf{1 6}$ & $\mathbf{1 2}$ & $\mathbf{4}$ & $\mathbf{0}$ & $\mathbf{0}$ & $\mathbf{0}$ & $\mathbf{1 0}$ & $\mathbf{2}$ \\
& & $75 \%$ & $25 \%$ & $0 \%$ & $0 \%$ & $0 \%$ & $62,5 \%$ & $12,5 \%$ \\
\hline \multirow{2}{*}{ medium } & $\mathbf{1 4}$ & $\mathbf{1 0}$ & $\mathbf{4}$ & $\mathbf{0}$ & $\mathbf{0}$ & $\mathbf{3}$ & $\mathbf{3}$ & $\mathbf{4}$ \\
& & $71 \%$ & $28,6 \%$ & $0 \%$ & $0 \%$ & $21,4 \%$ & $21,4 \%$ & $28,6 \%$ \\
\hline \multirow{2}{*}{ small } & $\mathbf{2 0}$ & $\mathbf{9}$ & $\mathbf{1 1}$ & $\mathbf{0}$ & $\mathbf{1}$ & $\mathbf{1}$ & $\mathbf{0}$ & $\mathbf{7}$ \\
& & $45 \%$ & $55 \%$ & $0 \%$ & $5 \%$ & $5 \%$ & $0 \%$ & $35 \%$ \\
\hline \multirow{2}{*}{ in total } & $\mathbf{5 0}$ & $\mathbf{3 1}$ & $\mathbf{1 9}$ & $\mathbf{0}$ & $\mathbf{1}$ & $\mathbf{4}$ & $\mathbf{1 3}$ & $\mathbf{1 3}$ \\
& & $62 \%$ & $38 \%$ & $0 \%$ & $2 \%$ & $8 \%$ & $26 \%$ & $26 \%$ \\
\hline
\end{tabular}

Explanation to the Table: A - less than 1 year, B - between 1-3 years, C - between 3-5 years, D - between 5-10 years, $\mathrm{E}$ - longer than 10 years.

Source: own work based on a survey.

In the research, we investigated factors (scale 0 - insignificant, 1 - minimal effort, 2 less significant, 3 - significant 4 - very significant, 5 - the most significant) which encouraged enterprises to start operating their business in SEZ located in Lower Silesia region (cf. Figure 2). While analyzing the factors, tax exemptions and reductions and local fees (including also those received within the so-called public aid) were the decisive factor for $83 \%$ of the surveyed enterprises and were significant or very significant for the rest of respondents. Another important factor was low price of land. $60 \%$ of the surveyed enterprises declared this factor as very significant and the most significant and the decisive one for starting a business operation. The price of land was the most noticeable as the most significant for $43 \%$ of respondents and especially among small enterprises (67\%). A similar level of indications was noted in the case of a convenient transport location. In $37 \%$ of responses, this factor was decisive for starting business operations in Lower Silesia SEZs, for 19\% it was a very significant factor, and for $11 \%$ not significant (response of medium and small enterprises). In the case of a well-developed technical infrastructure, the opinions of the surveyed enterprises were much divided. For $31 \%$ of surveyed enterprises, it was a determinant factor for starting business operations in investment privileged zones. In addition, for every fifth enterprise, (20\%) it was significant and $23 \%$ declared this factor as less significant. What is more, the factor distance from business partners was the most significant only for $25 \%$ of respondents but it is worth mentioning that it was the significant factor for small enterprises (40\%) and significant for the large one (33\%). 


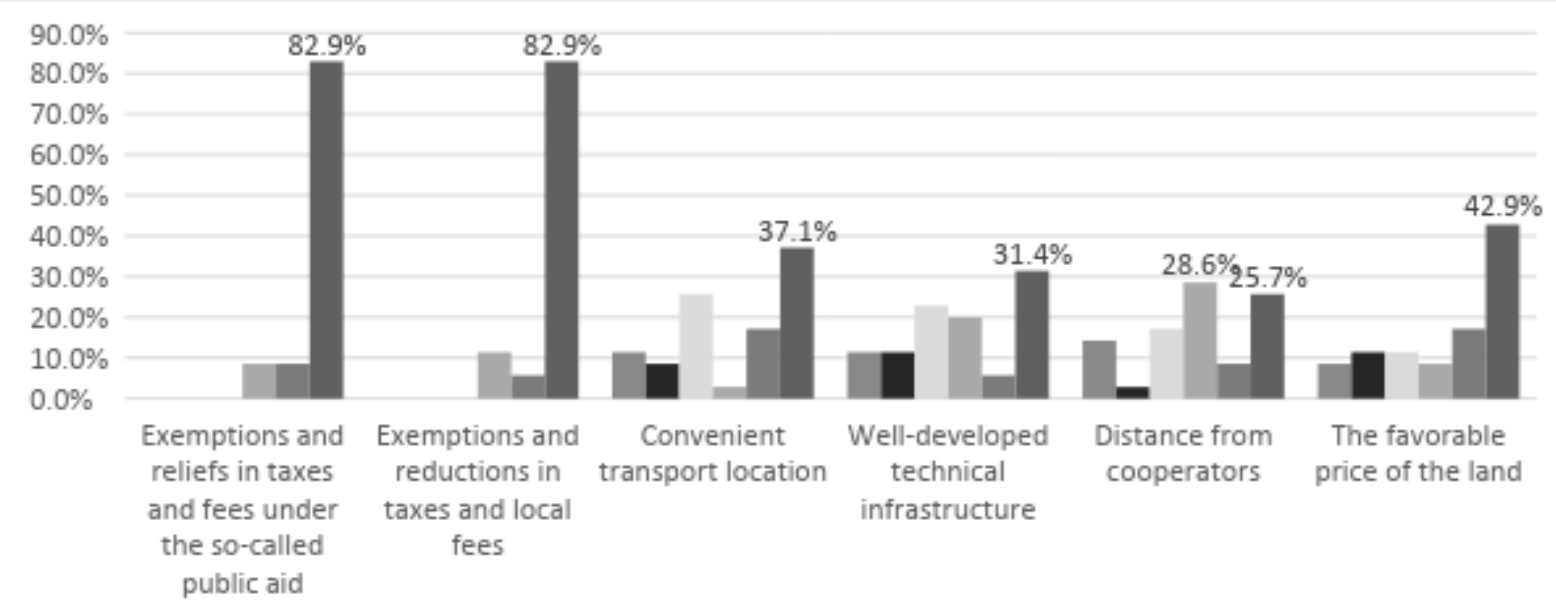

Figure 2. The significance of factors influencing the location of enterprises in Lower Silesia SEZs

Source: own elaboration based on the performed survey.

While conducting analysis on the effects of the way enterprises function in SEZs located in Lower Silesia region, the fact of existing cooperation links was examined (cf. Table 2).

Table 2. Structure of location of business partners of enterprises operating in Lower Silesia SEZs

\begin{tabular}{lcccccccc}
\hline \multirow{2}{*}{$\begin{array}{c}\text { Category of } \\
\text { enterprise }\end{array}$} & in total & no & \multicolumn{7}{c}{ Partnership and cooperation } \\
\cline { 2 - 9 } & & & $\mathrm{A}$ & $\mathrm{B}$ & $\mathrm{C}$ & $\mathrm{D}$ & $\mathrm{E}$ & $\mathrm{F}$ \\
\hline \multirow{2}{*}{ Large } & 10 & 3 & 0 & 0 & 3 & 2 & 2 & 0 \\
& & $30 \%$ & $0 \%$ & $0 \%$ & $30 \%$ & $20 \%$ & $20 \%$ & $0 \%$ \\
\cline { 2 - 9 } Medium-sized & 8 & 4 & 0 & 0 & 1 & 1 & 0 & 2 \\
& & $50 \%$ & $0 \%$ & $0 \%$ & $12 \%(12,5)$ & $12 \%(12,5)$ & $0 \%$ & $25 \%$ \\
\cline { 2 - 9 } Small & 9 & 3 & 0 & 0 & 1 & 2 & 2 & 1 \\
& & $33 \%$ & $0 \%$ & $0 \%$ & $11 \%$ & $22 \%$ & $22 \%$ & $11 \%$ \\
\hline \multirow{2}{*}{ In total } & 27 & 10 & 0 & 0 & 5 & 5 & 4 & 3 \\
& & $37 \%$ & $0 \%$ & $0 \%$ & $18 \%$ & $18 \%$ & $15 \%$ & $12 \%$ \\
\hline
\end{tabular}

Explanation to the Table: $\mathrm{A}$ - within the zone, $\mathrm{B}$ - within the zone and outside of it, $\mathrm{C}$ - outside the zone in the same location, D - outside the zone in a different location in Lower Silesia region, E - outside the zone in a different region, $\mathrm{F}$ - outside of Poland.

Source: own work based on a survey. 
As can be observed in Table 2, seventeen out of twenty-six enterprises (63\%) indicated that they have business partners. The biggest number of suppliers and recipients (23\%) was located outside the zone in a different location in Lower Silesia region, and their cooperation usually consisted in providing mutual services. None of the surveyed entities cooperated with enterprises operating within the SEZ and enterprises that function both within the zone and outside of it. $40 \%$ of the investigated enterprises have cooperators outside the zone in the Lower Silesian region and outside the region, and $11 \%$ of respondents had business partners outside Poland. The success of the investment depends not only on good cooperation between the entity operating a business in the area of SEZ and a management enterprise but also to an equal extent on support and aid from local government authorities. In fact, in the following situation, all three parties should undertake cooperation in order to make investments in privileged zones and in the region successful. Due to this fact, every tenth surveyed entity (12\%) had negative experiences with local government authorities and, as a result, provided a negative evaluation of cooperation with them (cf. Figure 3). On the other hand the majority of the surveyed entities qualified relationships with local authorities as very favourable and rather favourable.

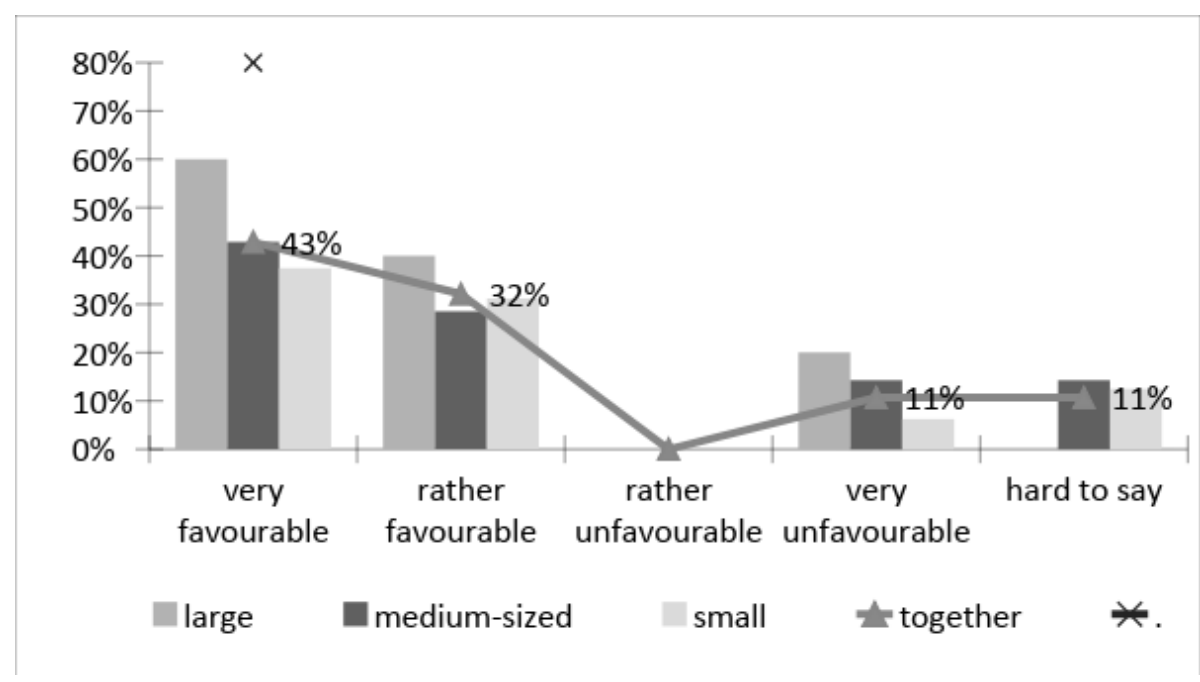

Figure 3. Evaluation of cooperation with local government authorities made by enterprises functioning in Lower Silesia SEZs

Source: own elaboration based on the performed survey.

The fact that a city or a commune belongs to SEZ means that it is introduced into an elite circle of local government units, operating to the benefit of gaining new enterprises. On the one hand, high standards, set recently by the enterprises managing particular privileged areas, give enterprises some kind of guarantee that offers for enterprises will be professionally prepared, and investment process will be as quick as possible. On the other hand, the expectations of business entities towards local authorities and authorities that manage the zones are rising, both those future ones and those functioning at present in economically privileged zones (Lizińska \& Kisiel, 2008, pp. 70-74). Among the expectations of enterprises operating their business in the area of Lower Silesia SEZs, towards local government authorities, the following issues dominated (cf. Figure 4): expectations connected with complete abolition of property tax (57\% of indications), $25 \%$ of respondents opted for bigger tax releases or the improvement of technical infrastructure (18\%). These expectations can also 
be justified, as among the factors that were crucial in starting business operation in Lower Silesia SEZs, the entrepreneurs most often indicated tax releases and reliefs in local fees (including also those granted from the socalled public aid).

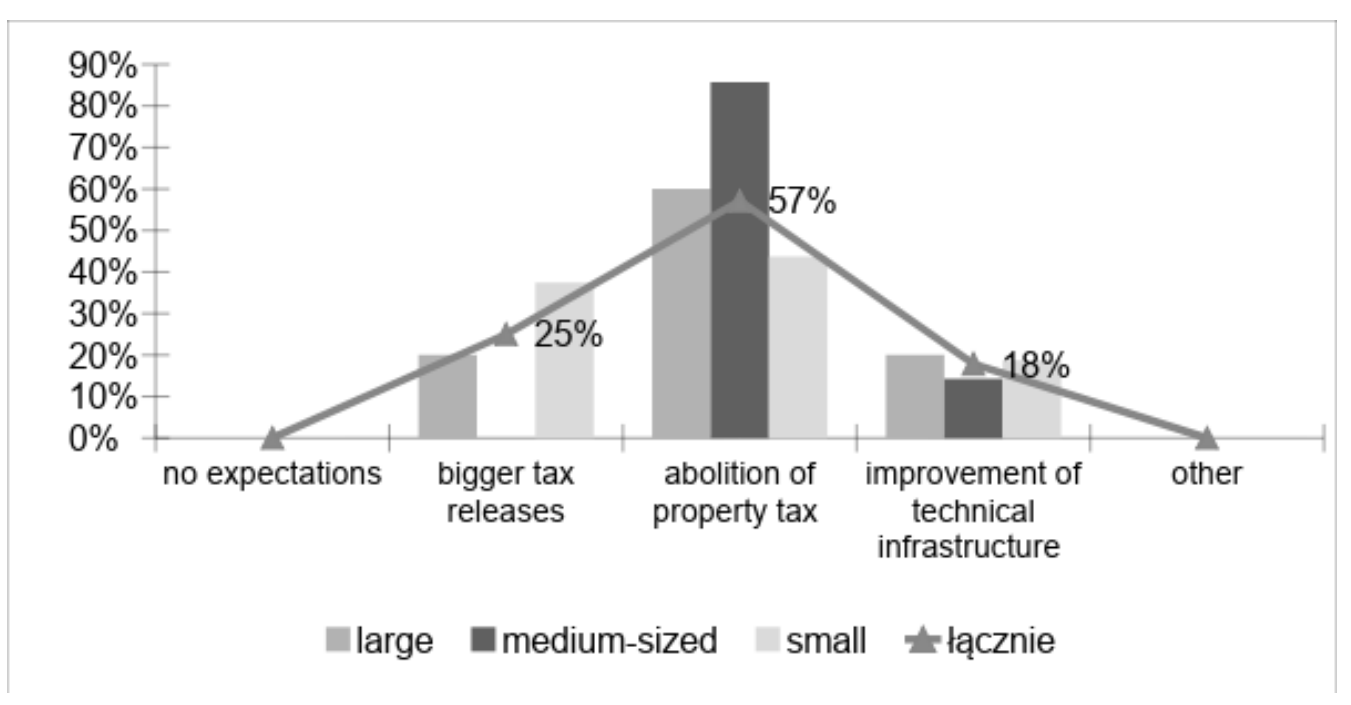

Figure 4. Expectations of Lower Silesia SEZs entrepreneurs towards local authorities Source: own elaboration based on the performed survey.

When it comes to cooperation with enterprises managing particular SEZs that function in the area of Lower Silesia, 57\% of the surveyed enterprises were positive about this kind of cooperation, and every third one $(25 \%)$ claimed that this cooperation is very favourable. Every tenth surveyed entity $(11 \%)$ had negative experiences with enterprises managing the zone and, as a result, evaluated the quality of this kind of cooperation in a negative way (cf. Figure 5).

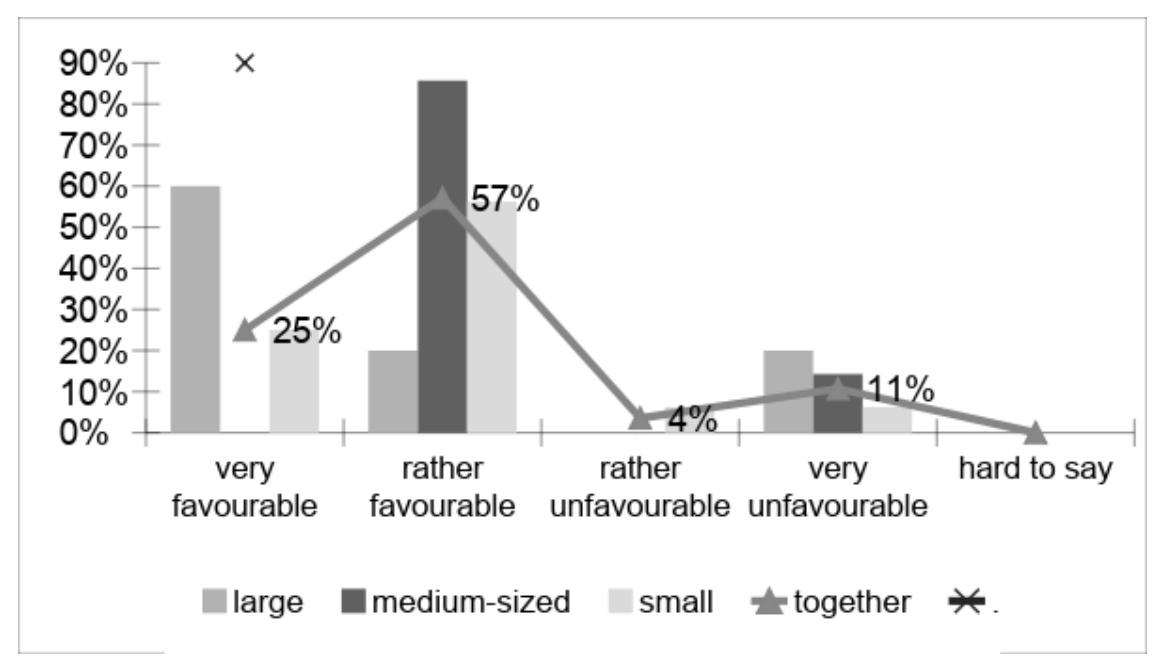

Figure 5. Evaluation of cooperation with zone management by enterprises that function in Lower Silesia SEZs

Source: own elaboration based on the performed survey. 
The main task of enterprises that formally manage Lower Silesia SEZs is to operate towards developing business activity in their area. In addition, the management should enable enterprises to use and benefit from the property lying within the zones, and manage technical structure facilities. One of the goals of management enterprises is also to create the conditions that enable provision of services to entities functioning within the zone and carry out promotional activities (Lizińska \& Kisiel, 2008, pp. 70-74).

The main expectations of enterprises that conduct business activities in SEZs, located in the area of Lower Silesia, in relation to management of the zones, were connected with legal $(42 \%)$ and financial advice (40\% of indications), aid with formal issues (36\%) and aid related to tax reliefs $(22 \%)$. The other indications mainly referred to the improvement of technical infrastructure (14\%), better cooperation, bigger tax exemptions, enlarging the area of sub-zones, lowering administration costs, helping to recruit employees and protect the natural environment and others (in total $42 \%$ ).

However, there are also negative consequences of functioning in SEZs. Conducting business activities in the area of Lower Silesia SEZs is connected with meeting a number of requirements, mainly of legal nature. This also creates many organizational problems. As for problems that were experienced by the surveyed enterprises functioning in the investment privileged zone that probably would not have been experienced to this extent outside of the zone, the most frequent responses concerned legal obstacles and confusing regulations (42\% of the indications). Relatively significant percentage of respondents (16\%) encountered problems connected with poorly developed infrastructure/logistics and personnel shortage (13\%). Additional costs (e.g. transport of employees) connected with operating in the area of the zone, cooperation with local government authorities and enterprises managing privileged areas, as well as low level of cooperation with research and development centres turned out to be an obstacle for nearly every tenth surveyed enterprise (cf. Figure 6).

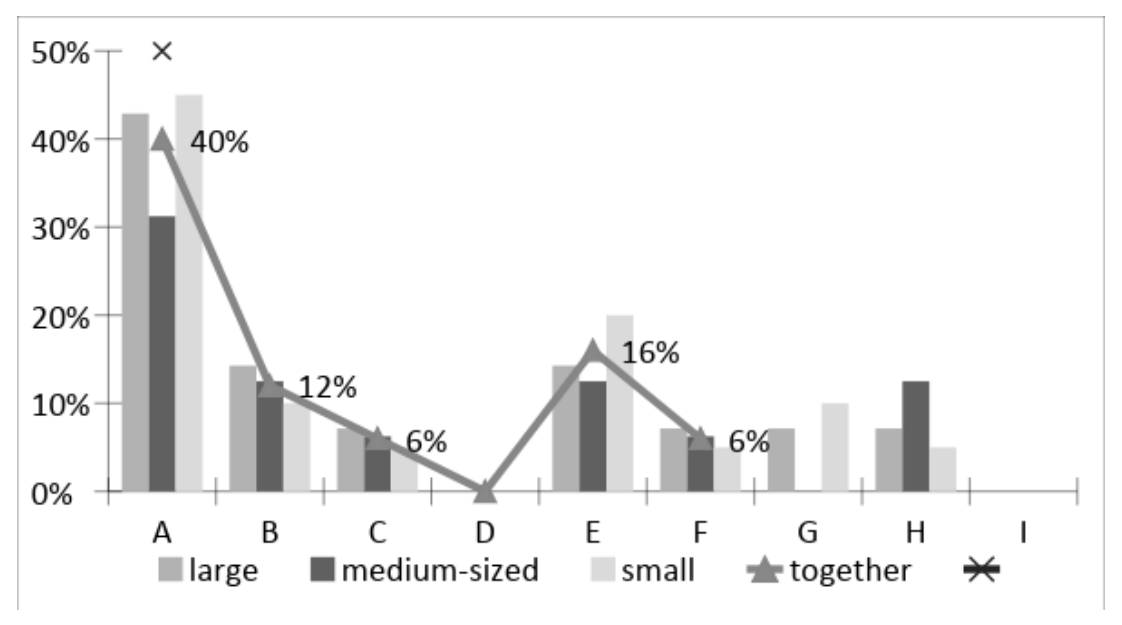

Explanations to the Figure: A - legal obstacles and confusing regulations, B - shortage of personnel, C additional costs, D - limited space for enterprise development, E - poorly developed infrastructure/logistics, F cooperation with local authorities/zone management, $\mathrm{G}$ - lack/low level of cooperation with research and development centres, $\mathrm{H}$ - lack of problems, I - others.

Figure 6. Problems observed by inventors, functioning in Lower Silesia SEZs, which would probably have been avoided while operating outside the zone

Source: own elaboration based on the performed survey.

Supporters of the thesis about a growing role of economically privileged zones indicated that tax exemptions and reliefs will continue to attract new enterprises. Every fifth 
enterprise pointed out that belonging to the zone is profitable and contributes to the enterprise development. Apart from that, conducting business activities in investment privileged areas is beneficial not only from the financial point of view but also organizational and operational ones - it is possible to count on the support from zone management and local government authorities. It seems that enlarging the area of the zones up to 20,000 ha will constitute an impulse which may encourage many new enterprises to enter the zone.

Furthermore, it can be stressed that the development of SEZs is being continued and in 2017 new permits were granted. In Wałbrzych SEZ it was 34 permits which should result in 700 new jobs. Capital expenditures in 2017 declared by investors amounted toca. PLN 1.1 billion (from the beginning of the SEZ existence it is ca. PLN 26 billion and employ 52,500 people). In Kamienna Góra SEZ it was 4 permits what should results in 78 new jobs. Capital expenditures in 2017 declared by investors was ca. PLN 125 million (from the beginning of the SEZ existence it is ca. PLN 2.5 billion and employ 7,600 people). In Legnica SEZ it was 11 permits which should results in 614 new jobs. Capital expenditures in 2017 declared by investors amounted ca. PLN 869 million (from the beginning of the Wałbrzyska SEZ existence it has been ca. PLN 8 billion and SEZ employs 15,000 people.

\section{Conclusion}

In the light of the above research results, it can be stated that nowadays more attention is paid to the benefits arising from cooperation among market participants on a local scale. It may become a basis for creating a cooperation network of a regional, national and international scope and significance. It can be said that the research correlates more broadly with the mainstream EU public policies and national policies on interionalization of economic activities, through dedicated instruments (often publicly subsidized), such as initiatives for the internationalization of the so-called national key clusters (part of which are SEZs) coordinated by Polish Agency for Enterprise Development (PARP). The activities of the Polish Investment and Trade Agency aimed at exporting Polish enterprises - Go China, Go Africa (and a special cell inside the Agency cooperating with the zones) are worth mentioning.

The creation of SEZs translates not only into cooperation among entrepreneurs located within SEZs but also into cooperation that reaches beyond the zone and creation of cooperative associations of a wider impact. As it is clear from the studied academic literature and reference documents, supporting the phenomenon of cooperation is not an easy task and requires cooperation of many market participants. However, as the experience of other countries shows, it is definitely attainable. In Poland, activities connected with this issue are already in progress and continuing them while using other countries' experiences may ensure success. Although research entities indicated legal obstacles, confusing regulations, shortage of personnel, or limited space for enterprise development in SEZs in Lower Silesia they qualified relationships with local authorities as very favourable and rather favourable. Researched entities also recognized the crucial role of authority formally managing SEZs.

It needs to be outlined that despite identified unfavourable conditions for business conduct, the researched entities invested in new technologies, services and further expansion. The following deliberations prove that role of local authorities and SEZs managing authorities in the creation of overall business environment is essential for entities in SEZ and further to local development. There is a significant focus on local authorities, resulting from the possibility of direct contacts with business entities, as it facilitates noticing and identification of arising problems and helps indicate solutions or inspire to act towards solving them.

On the basis of the conducted empirical study and on the surveyed entrepreneurs operating in Lower Silesia SEZs, it can be stated that the enterprises evaluate their 
functioning in the zones in a positive way. The creation of Kamienna Góra, Legnica and Wałbrzych zones attracted foreign and national capitals to Lower Silesia region. Both large, medium-sized and small enterprises appeared to be investors, and some of them had already functioned in this region before.

The factor, with the biggest impact on creating a business in SEZs, located in Lower Silesia region was tax exemption and relief in local fees (including also the so-called public aid). Another crucial factor was the beneficial price of land and convenient location. Respondents mentioned significantly less often such reasons as relative "cheapness" of employees and the level and structure of professional qualifications of employees.

As regards the biggest barriers hindering investments in economically privileged zones, the surveyed enterprises mentioned unclear and complicated legal provisions referring to operating a business, local authorities' attitude towards those entities that function in Lower Silesia SEZs, bureaucracy in local institutions, long-lasting and complicated procedures connected with starting a business (new investment), and additionally problems with recruiting appropriate employees.

With regard to local government authorities, the entrepreneurs mostly expected a complete abolition of property tax, bigger tax exemptions and improvement of technical infrastructure. What dominated among expectations from the enterprises operating their business in SEZs located in Lower Silesia region towards zone administrators were the expectations connected with legal and tax advice and assistance in settling the formalities. The rest of indications referred mainly to the improvement of technical infrastructure, better cooperation, bigger tax exemptions, enlarging the area of sub-zones, lowering administration costs, help in recruiting employees and protecting the natural environment.

Due to the recognized phenomena, we find further research of entities functioning in SEZs highly justified, with particular attention to creation, maintenance and nurturing of the relationship between economic entities, local authorities and SEZs managing authorities. The established relations might be a key explanatory factor for overall business benefits perception from location and business conduct in SEZs.

\section{References}

Aggarwal, A. (2006). Special Economic Zones. Revisiting the Policy Debate. Economic and Political Weekly, 41(43/44), pp. 4533-4536, doi:10.1093/acprof:oso/9780198077275.001.0001.

Aggarwal, A. (2010). Economic impacts of SEZs: Theoretical approaches and analysis of newly notified SEZs in India. MPRA. Retrieved January 8, 2018, from https://mpra.ub.uni-muenchen.de/id/eprint/20902.

Bagnasco, A. (1977). Tre Italie. La problematica territoriale dello sviluppo italiano. Bologna: Il Mulino.

Baissac, C. (2011). Brief History of SEZs and Overview of Policy Debates. In: T. Farole (ed.), Special Economic Zones in Africa: Comparing Performance and Learning from Global Experience (pp. 23-60). Washington, DC: World Bank.

Becattini, G. (1992). Le district marshallien: une notion socio-économique. In: G. Benco, A. Lipietz (eds.), Les regions qui gagnent (pp. 35-55). PUF, Paris.

Becattini, G. (1979). Dal settore industriale al distretto industriale: Alcune considerazioni sullunità di indagine delleconomia industrial. Rivista di Economia e Politica Industriale, 1, 7-21. 
Bell, T. W. (2016). Special Economic Zones in the United States: From Colonial Charters to Foreign-Trade Zones, Toward USSEZs. Buffalo Law Review, 64, 959-1007. doi:10.2139/ssrn. 2743774.

Büttner, S., Heidenreich, M. (2005). The Lower Silesia Economic Region 2005, Retrived May 17, 2018, from http://www.sozialstruktur.unioldenburg.de/dokumente/Lower\%20Silesia\%20(3_2005).pdf.

Ciżkowicz, P. \& Ciżkowicz-Pękała, M. \& Pękała, P. \& Rzońca, A. (2017). The effects of special economic zones on employment and investment: spatial panel modelling perspective. Journal of Economic Geography, 17, 571-605. doi:10.1093/jeg/lbw028.

Dahmén, E. (1950). Svensk Industriell Företagsverksamhet, Kausalanalys av den Industriella Utvecklingen 1919-1939. Doktorsavhandling, Stockholm Stockholm: IUI.

Domanski, B., \& Gwosdz, K. (eds.) (2005). Ten years of experience in first Polish Special Economic Zone Mielec 1995-2005, ARP, Management, Krakow, 13(1), 1-8.

Farole, T. (2011). Introduction. In: T. Farole (ed.). Special Economic Zones in Africa: Comparing Performance and Learning from Global Experience. 17-22. Washington, DC: World Bank.

García-Merino, J. D., \& García-Zambrano, L., \& Rodriguez-Castellanos, A. (2014). Impact of Relational Capital on Business Value. Journal of Information \& Knowledge Management, 13(1), 1-8. doi.org/10.1142/S0219649214500026.

Godlewska-Majkowska, H., \& Komor, A. \& Typa, M. (2016). Special Economic Zones as Growth and Anti-growth Poles as Exemplified by Polish Regions. EBER, 4(4), 189-212.

Grubel, H. G. (1982). Towards a theory of free economic zones Review of World Economics, 91180, 39-61.

Hazakis, K. J. (2014). The rationale of special economic zones (SEZs): An Institutional approach. Regional Science Policy \& Practice, 6(5), 85-101. doi:10.1111/rsp3.12030.

Komarovskiy, V., \& Bondaruk, V. (2013). The Role of the Concept of Growth Poles for Regional Development. Journal of Public Administration, Finance and Law, 4/2013, $31-42$.

Kubin, T. (2010). Specjalne Strefy Ekonomiczne jako forma pomocy przedsiębiorstwom ze strony państwa [Special Economic Zones as a form of state aid for enterprises]. In: M. Kolczyński, W. Wojtasik (eds.). Innowacyjne i spoteczne oddziaływanie specjalnych stref ekonomicznych $i$ klastrów w Polsce [Innovative and social impact of special economic zones and clusters in Poland]. 7-36, Katowice: Towarzystwo Inicjatyw Naukowych. Society for Scientific Initiatives.

Lizińska, W., \& Kisiel, R. (2008). Specjalne strefy ekonomiczne jako instrument polityki regionalnej na przykładzie Warmińsko-Mazurskiej Specjalnej Strefy Ekonomicznej [Special economic zones as an instrument of regional policy on an example of the Warmia and Mazury Special Economic Zone]. Olsztyn: Pub. University of Warmia and Mazury in Olsztyn.

Kryńska, E. (ed.) (2000). Polskie specjalne strefy ekonomiczne - zamierzenia i efekty [Polish Special Economic Zones - intentions and effects]. Warszawa: Wydawnictwo Naukowe Scholar, Warsaw: Scientific Publishing House Scholar.

Marshall, A. (1920). Principles of economies, Macmillan. London, 348-358.

McCalla, R. J. (1990). The geographical spread of free zones associated with ports. Geoforum, 21(1), 121-134.

Meyer-Stamer, J. (1999). Strategien lokaler/regionaler Entwicklung: Luster, Standortpolitik und systemische Wettbewerbfähigkeit. Institut für Entwicklung und Frieden, Universität Duisburg, Duisburg. 
Moberg, L. (2015). The political economy of special economic zones. Journal of Institutional Economics, 11(1), 167-190. doi:10.1017/S1744137414000241.

Perroux, F. (1950). Economic Spaces: theory and application. Quarterly Journal of Economics, 64(1), 90-97.

Pietrzyk, I. (2001). Polityka regionalna Unii europejskiej i regiony państw członkowskich [Regional Policy of the European Union and regions of the Member States]. Warszawa: PWN.

Porter, M. E. (1990). The Competitive Advantage of Nations. Free Press, New York.

Pyke, F., \& Sengenberger, W. (1992). Industrial districts and local economic regeneration. International Institute for Labor Studies, Geneva.

Semlinger, K. (2008). Cooperation and competition in network governance: regional networks in a globalised economy. Entrepreneurship \& Regional Development, 20(6), 547-560. doi:10.1080/08985620802462157.

UNCTC (1991). The challenge of free economic zones in Central and Eastern Europe: International Perspectives. United Nations, New York.

Ustawa z dnia 20 października 1994 r. o specjalnych strefach ekonomicznych. The Act of 20 October 1994. on special economic zones - DzU 1994, No. 123, pos. 600, consolidated text: DzU 2007, no. 42, pos. 274 with later amendments).-miejscem-do-wspolpracynauki-i-biznesu.html (access: 15.04.2014).

World Bank (2008). Special economic zones. Performance, lessons learned, and implications for zone development. Washington, DC: World Bank.

www.paih.gov.pl, Retrived April 17, 2018, from https://www.paih.gov.pl/strefa_inwestora/sse Zdyb, M. (1997). Publiczne prawo gospodarcze. Public business law. Kraków: Kantor Wydaw. Zakamycze. 